\title{
REPRESENTASI PENDIDIKAN PADA FILM JEMBATAN PENSIL
}

\author{
Devi Heryanti \& Yostiani Noor Asmi Harini \\ Departemen Pendidikan Bahasa dan Sastra Indonesia \\ FPBS, Universitas Pendidikan Indonesia \\ deviheryanti0@gmail.com
}

\begin{abstract}
ABSTRAK
Film Jembatan Pensilgarapan sutradara Hasto Broto yang dirilis pada September 2017 menceritakan tentang anak-anak pelosok desa Pulau Muna, Sulawesi Tenggara yang sangat sulit untuk meraih pendidikan. Pada artikel ini dideskripsikanstruktur film dengan pendekatan sosiologi sastra. Berdasarkan hasil analisis, film Jembatan Pensil merepresentasikan ketidakmerataan pendidikan di Pulau Muna serta sulitnya akses jalan yang ditempuh menjadi hambatan masuknya pendidikan. Selain itu, belum adanya campur tangan pemerintah yang mengakibatkan pendidikan kurang terjangakau. Sosok Ondeng tampil sebagai pahlawan untuk memperbaiki jembatan yang rapuh dengan menabungkan uang jajannya. Keterbelakangan mental yang dimiliki tokoh Ondeng merupakan satir terhadap masyarakat dan pemerintah.
\end{abstract}

Kata kunci: Jembatan Pensil, struktur film, dan representasi pendidikan

\section{PENDAHULUAN}

Dewantara (2004) mendefinisikan pendidikan sebagai tuntunan di dalam hidup seseorang. Pendidikan diharapkan dapat menuntun tumbuh kembangnya manusia agar dapat mencapai keselamatan dan kebahagiaan yang setinggi-tingginya. Pendidikan begitu penting posisinya dalam kehidupan setiap insan. Oleh sebab itu, isu mengenai pendidikan dapat kita lihat dalam berbagai karya sastra termasuk film.

Film Jembatan Pensilkarya Hasto Broto yang dirilis pada September 2017 mengusung isu pendidikan di Sekolah Dasar yang dienyam oleh anak-anak pelosok desa Pulau Muna, Sulawesi
Tenggara. Dalam film tersebut, pendidikan dikisahkan sebagai sesuatu yang sulit diakses karena berbagai persoalan salah satunya adalah ketidakmerataan pendidikan. Hal tersebut terjadi karena permasalahan fasilitas pendukung pendidikan seperti akses jalan serta kurangnya kepedulian pemerintah dan masyarakat.

Film sebagai produk masyarakat dapat dilihat sebagai sarana representasi realitas dalam masyarakat yang berfungsi sebagai dokumen dari realitas sosial budaya, maupun politik yang terjadi (Wiyatmi, 2013). Dalam videonya yang diunggah di Youtube, Lamb (2013) mengemukakan bahwa dalam media 
(misalnya film) terdapat representasi. Representasi tersebut dikonstruksi sedemikian rupa melalui bagaimana film tersebut disajikan. Pada artikel ini dideskripsikan representasi pendidikan pada film Jembatan Pensil sebagai dokumen dan realitas sosial budaya. Untuk memperoleh data tersebut, peneliti mengidentifikasi skema aktan dan model fungsional Greimas, tokoh, dan latar yang terdapat dalam film.

\section{HASIL DAN PEMBAHASAN}

Greimas yang dikutip oleh Harini (2012) menuliskan bahwa aktan adalah satuan naratif terkecil. Melalui aktan, akan terlihat hubungan-hubungan yang terjadi dalam cerita. Terdapat enam fungsi aktan dalam tiga pasangan oposisional. Jika disusun dalam sebuah skema, tiga pasangan oposisional aktan tersebut digambarkan sebagai berikut.

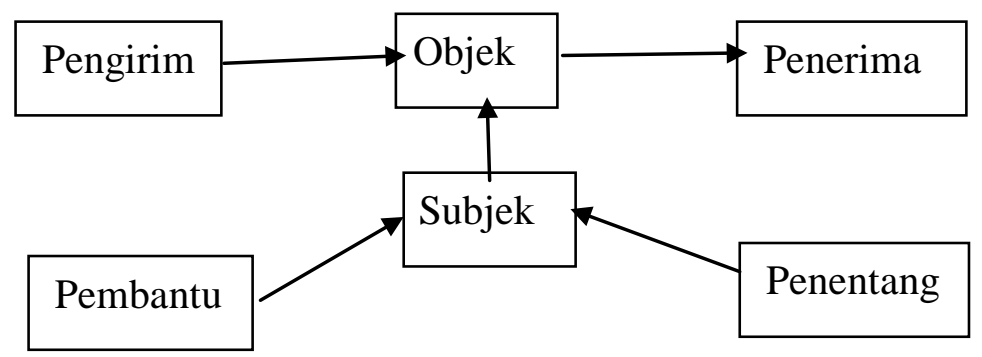

Gambar 1 Skema Aktan

Selanjutnya, Greimas seperti dibahas Harini (2012)mencatat bahwa tanda panah dalam skema aktan menjadi unsur penting yang mengubungkan fungsi tiap-tiap aktan. Pengirim adalah seseorang atau sesuatu yang menjadi sumber ide dan Pengirimlah yang menimbulkan karsa bagi subjek atau pahlawan untuk mencapai objek. Objek adalah seseorang atau sesuatu yang diingini, dicari, dan diburu oleh pahlawan atau ide pengirim. Subjek adalah seseorang atau sesuatu yang ditugasi oleh pengirim untuk mendapatkan objek. Penolong adalah berfungsi sebagai penggerak cerita.

sesuatu yang membantu atau mempermudah usaha pahlawan dalam mencapai objek. Penerima adalah sesuatu yang menerima hasil buruan subjek. Penentang adalah seseorang atau sesuatu yang menghalangi usaha pahlawan dalam mencapai objek.

Selain mengemukakan skema aktan, Greimas juga mengemukakan model fungsional. Greimas seperti dibahas Jabrohim (1996: 16) menyebutkan bahwa model fungsional mempunyai tugas menguraikan peran subjek dalam rangka melaksanakan tugas dari pengirim yang 
FON ; Jurnal Pendidikan Bahasa dan Sastra Indonesia

Volume 13 Nomor 2 Tahun 2018

terdapat dalam aktan. Berikut adalah model fungsional:

Tabel 1 Model Fungsional

\begin{tabular}{|l|l|l|l|l|}
\hline \multirow{2}{*}{$\begin{array}{l}\text { Situasi } \\
\text { Awal }\end{array}$} & \multicolumn{3}{|c|}{ Transformasi } & \multirow{2}{*}{ Situasi } \\
\cline { 2 - 5 } & $\begin{array}{l}\text { Tahap uji } \\
\text { kecakapan }\end{array}$ & $\begin{array}{l}\text { Tahap } \\
\text { utama }\end{array}$ & $\begin{array}{l}\text { Tahap } \\
\text { Kegemilangan }\end{array}$ & Akhir \\
\hline & & & & \\
\hline
\end{tabular}

Situasi awal, cerita diawali oleh diuraikan apakah subjek mendapat adanya karsa atau keinginan untuk rintangan atau tidak dalam rangka mendapatkan sesuatu. Pada tahap mencapai objek. Pada kegemilangan transformasi terdapat tiga tahap yaitu dipaparkan keberhasilan subjek dalam tahap uji kecakapan, tahap utama, dan mencapai objek. Pada tahap akhir, tahap kegemilangan. Tahap uji kecakapan dipaparkan berakhirnya konflik (Jabrohim merupakan tahapan yang menceritakan 1996: 17-19). Berikut ini skema aktan dan mulainya usaha subjek untuk bergerak model fungsional film Jembatan Pensil. mencapai objek. Pada tahap uji coba

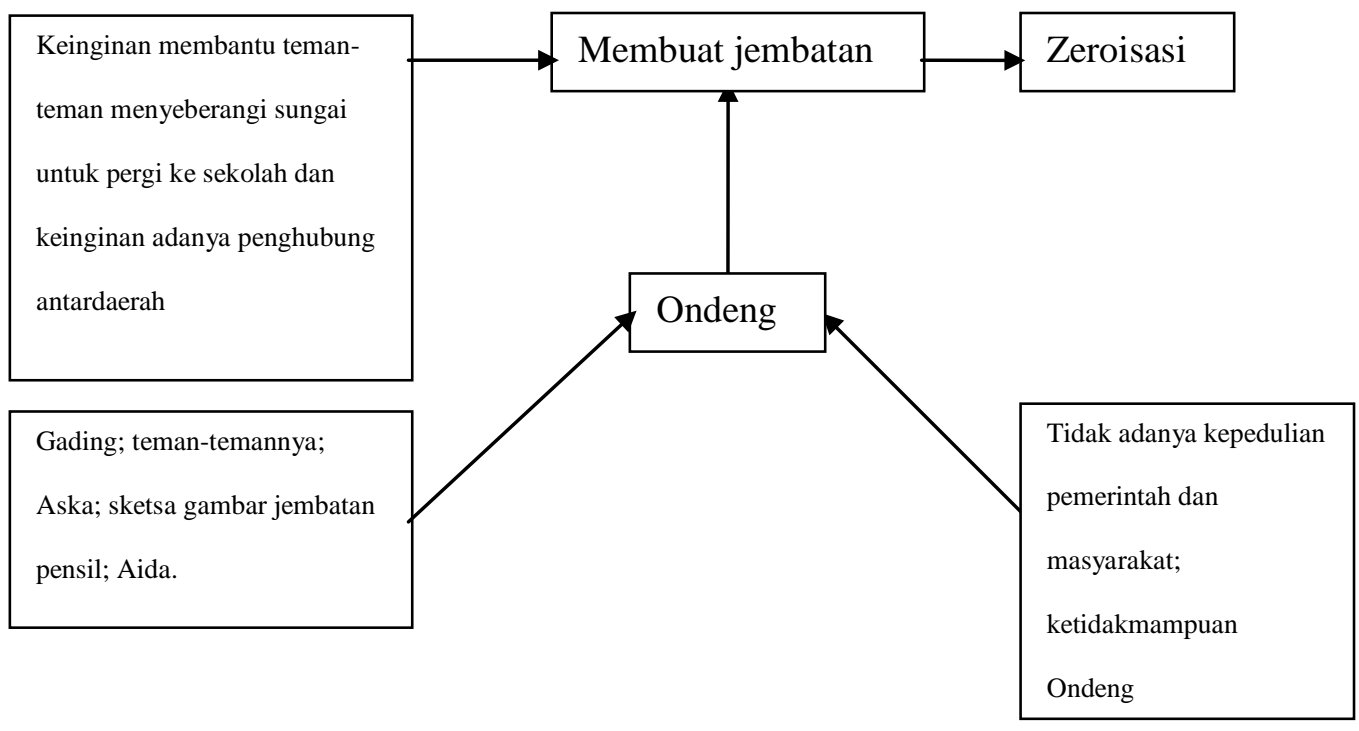

Gambar 2 Skema Aktan Ondeng 
FON ; Jurnal Pendidikan Bahasa dan Sastra Indonesia

Volume 13 Nomor 2 Tahun 2018

Tabel 2 Model Fungsional Ondeng

\begin{tabular}{|c|c|c|c|c|}
\hline \multirow[b]{2}{*}{$\begin{array}{l}\text { Tahap } \\
\text { Awal }\end{array}$} & \multicolumn{3}{|c|}{ Transformasi } & \multirow[b]{2}{*}{ Tahap Akhir } \\
\hline & $\begin{array}{l}\text { Uji } \\
\text { Kecakapan }\end{array}$ & Tahap Utama & Tahap Keberhasilan & \\
\hline $\begin{array}{l}\text { Kondisi } \\
\text { jembatan } \\
\text { yang } \\
\text { rapuh. }\end{array}$ & $\begin{array}{l}\text { Rasa iba } \\
\text { Ondeng pada } \\
\text { teman- } \\
\text { temannya } \\
\text { untuk } \\
\text { membuatkan } \\
\text { jembatan. }\end{array}$ & $\begin{array}{l}\text { Dikumpulkann } \\
\text { ya uang jajan } \\
\text { Ondeng } \\
\text { Dibuatnya } \\
\text { sketsa } \\
\text { jembatan }\end{array}$ & $\begin{array}{l}\text { Diucapkannya } \\
\text { keinginan Ondeng } \\
\text { oleh Bapaknya } \\
\text { kepada Gading. } \\
\text { mpi Ondeng dengan } \\
\text { sepotong pensil } \\
\text { ketika belajar pada } \\
\text { alam. }\end{array}$ & $\begin{array}{l}\text { Situasi } \\
\text { akhirnya tokoh } \\
\text { tidak bisa } \\
\text { mewujudkan } \\
\text { mimpinya } \\
\text { karena sakit } \\
\text { dan akhirnya } \\
\text { meninggal } \\
\text { dunia. }\end{array}$ \\
\hline
\end{tabular}

Berdasarkan skema aktan dan model fungsional Ondeng di atas, tampak bahwa yang paling menggerakkan cerita adalah keinginan Ondeng membantu teman dan masyarakat sekitar dengan membangun jembatan. Jembatan ini ingin Ondeng bangun untuk mempermudah teman- adalah skema aktan dan model fungsional temannya untuk pergi ke sekolah demi Gading meraih pendidikan. Sayang, meskipun ada

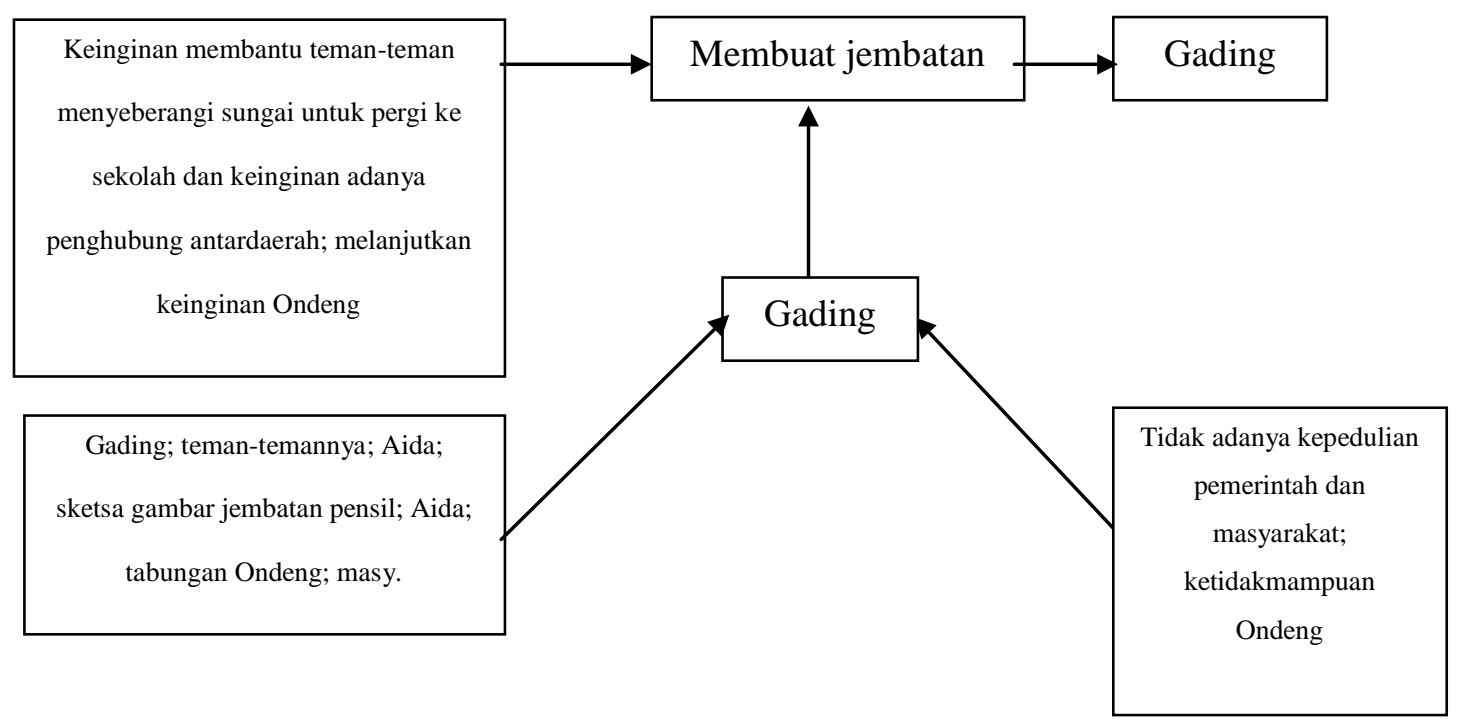

Gambar 3 Skema Aktan Gading 
FON ; Jurnal Pendidikan Bahasa dan Sastra Indonesia

Volume 13 Nomor 2 Tahun 2018

\begin{tabular}{|c|c|c|c|c|}
\hline \multirow[b]{2}{*}{ Tahap Awal } & \multicolumn{3}{|c|}{ Transformasi } & \multirow[b]{2}{*}{ Tahap Akhir } \\
\hline & $\begin{array}{l}\text { Uji } \\
\text { Kecakapan }\end{array}$ & Tahap Utama & $\begin{array}{l}\text { Tahap } \\
\text { Keberhasilan }\end{array}$ & \\
\hline $\begin{array}{l}\text { Sulitnya } \\
\text { akses } \\
\text { memperoleh } \\
\text { pendidikan; } \\
\text { kondisi } \\
\text { jembatan } \\
\text { yang } \\
\text { memprihatink } \\
\text { an; kematian } \\
\text { Ondeng. }\end{array}$ & $\begin{array}{l}\text { Diucapkanny } \\
\text { a janji Gadng } \\
\text { untuk } \\
\text { mewujudkan } \\
\text { impian } \\
\text { Ondeng }\end{array}$ & $\begin{array}{l}\text { Digunakannya } \\
\text { uang tabungan } \\
\text { Ondeng untuk } \\
\text { membangun } \\
\text { jembatan }\end{array}$ & $\begin{array}{l}\text { Tergugahnya } \\
\text { masyarakat, } \\
\text { teman-teman } \\
\text { Ondeng }\end{array}$ & $\begin{array}{l}\text { Dibangunnya } \\
\text { Jembatan } \\
\text { Pensil }\end{array}$ \\
\hline
\end{tabular}

Tabel 3 Model Fungsional Gading

Pada skema aktan dan model Dalam film ini, tokoh Ondeng yang fungsional di atas, tampak bahwa akses diperankan oleh Didi Mulya merupakan memperoleh pendidikan direpresentasikan tokoh utama dalam film. Ondeng kisahkan sebagai sesuatu yang sulit. Hal itu memiliki keterbelakangan mental. direpresentasikan secara simbolis melalui Meskipun demikian, tokoh ini dicitrakan sulitnya membangun jembatan pensil. sebagai tokoh yang sangat ceria dan penuh Penggunaan judul “Jembatan Pensil” semangat. Ia selalu menunggu sahabatdapat dimaknai pula sebagai jembatan sahabatnya diujung jembatan untuk pendidikan. Pensil dalam film tersebut memastikan sahabatnya sampai dengan berkaitan erat dengan media untuk selamat mengingat kondisi jembatan yang mencatat pelajaran. Hal ini dapat sudah sangat rapuh.

dimaknai pula sebagai sesuatu sarana

Rasa iba Ondeng munculsetelah meraih pendidikan yang lebih baik. Untuk memiliki mimpi ingin membuatkan dapat meraih pendidikan dengan lebih jembatan yang rapuh untuk sahabatbaik, diperlukan kerjasama dari berbagai sahabatnya agar dapat menyebrangi pihak.

Dalam film ini, relasi antartokoh merepresentasikan konflik yang terjadi. untuk memperbaiki jembatan tersebut. Satu tokoh dapat pula menempati posisi Meskipun kurang cerdas dalam hal sebagai pembantu maupun penentang. akademik, Ondeng memiliki kemampuan 
FON ; Jurnal Pendidikan Bahasa dan Sastra Indonesia

Volume 13 Nomor 2 Tahun 2018

menggambar sketsa. Keahliannya sebagai mata pencaharian Ibunya, pecahan membuat sketsa gambar membuat Ondeng batu tersebut masuk kedalam mata Inal, termotivasi membuat jembatan berbentuk dan minimnya akses kesehatan seperti pensil. Namun pada akhirnya menjadikan Inal sangat lamban ditangani sketsa tersebut dijadikan desain jembatan oleh medis hingga mengakibatkan Inal yang sama persis dengan jembatan yang akan diperbaiki. Kebaikan Ondeng semasa hidupnya dikenang oleh sahabatsahabatnya, meskipun sang tokoh harus pergi karena kecelakaan di laut lepas. Dalam menjalankan misinya, tokoh Ondeng dibantu oleh sahabat-sahabatnya: Aska, Inal, Nia, Yanti, dan Aska yang diperankan oleh Aska Marzuqi memiliki karakteristik yang pintar. Ia adalah salah satu sahabat Ondeng yang selalu membela Ondeng ketika ia dirisak teman sekelasnya. Sikap jujur Aska terlihat ketika ujarannya mengenai jembatan yang runtuh dan mengakibatkan ia dan temantemannya terlambat pergi sekolah. Tokoh Aska memiliki sikap yang peduli terhadap sahabatnya, terlihat pada adegan Aska yang selalu menuntun Inal (anak tuna netra) untuk pergi kesekolah.

Inal yang diperankan oleh Angger Bayu merupakan tokoh tuna netra. Meskipun begitu, Inal bukanlah tokoh yang pesimis, ia selalu pergi kesekolah bersama sahabat-sahabatnya yang lain dan dituntun Aska. Kebutaan Inal disebabkan ketika Inal hendak memecahkan batu, kehilangan penglihatannya.

Nia (Nayla D. Purnama) merupakan tokoh selanjutnya dan merupakan adik kandung dari Inal. Nia memiliki karakteristik yang baik hati, jujur, ceria, serta cerdas. Selain itu Nia merupakan salah satu sahabat Ondeng di sekolah. Yanti (Permata Jingga) memiliki karakteristik baik hati, pintar, cantik, setia kawan, bercita-cita menjadi dokter, kebanggaan orang tua, dan jujur. Citacitanya sebagai dokter terbukti pada percakapan Yanti dan Ibunya, karena di kampungnya belum ada dokter. Selain itu, Yanti rajin sekali berjualan kue buatan ibunya disekolah. Ibunyapun merasa bangga dengan prestasi anaknya. Yanti juga merupakan salah satu sahabat Ondeng.

Sahabat Ondeng yang kemudian mampu mewujudkan keinginan Ondeng ialah Gading. Gading yang diperankan Kevin Julio ini merupakan tokoh pemuda yang berprofesi sebagai nelayan.Setiap pergi melaut Gading selalu ditemani Pamone (bapak Ondeng). Sikapnya yang rendah hati membuat Aida jatuh cinta. 
Tokoh Gading memiliki sikap penolong sesama, terbukti pada adegan membantu Aida ketika tasnya tercebur ke air dan ketika Aida kedinginan diatas peralu Gading rela meminjamkan jaketnya. Gading merupakan anak yatim piatu. Ketika Ondeng ditinggal bapaknya Gadinglah yang merawat Ondeng serta ketika Ondeng meninggal Gadinglah yang meneruskan mimpi Ondeng untuk membuatkan jembatan bagi sahabatsahabatnya untuk akses pergi kesekolah. Selain tampan, Gading menyukai bukubuku tentang sastra, terlihat ketika ia membaca buku diatas perahu ketika sedang pergi mencari ikan.

Tokoh selanjutnya adalah Aida yang diperankan oleh Alisia Rininta, yang berperan sebagai anak dari Pak guru, dan baru saja menyelesaikan kuliahnya di Jakarta. Tokoh Aida ini memiliki sifat baik hati, dan peduli pada masyarakat sekitarnya. Selain itu watak dari tokoh Aida ini kreatif terlihat pada cara mengajarnya yang mengajak muridmuridnya belajar pada alam. Tokoh Aida ini seperti memiliki rasa pada Gading, karena sering dibantu tanpa meminta upah. Parasnya yang cantik membuat Gading pun memiliki rasa yang sama, selain itu Arman anak peternak sapi pun menyimpan rasa padanya.
Tokoh Pak Guru diperankan oleh Andi Bersama yang memiliki karakteristik rendah hati, terbukti pada kebaikannya membuat sekolah (SD Towea) gratis untuk masyarakat sekitar. Selain itu kebaikan Pak Guru ini tidak pernah mendapatkan imbalan dari pemerintah karena beliau berpendapat imbalannya hanya ada di akhirat. Ciri selanjutnya adalah Pak Guru seorang tokoh yang baik hati serta bijaksana. Terlihat ketika sedang menasihati Attar yang membuly Ondeng. Tokoh Farida (Meriam Bellina) ini merupakan Ibu dari Aida dan istri dari Pak Guru. Sikapnya yang pemarah dan tidak sabaran menjadikan karakteristik yang khas dan cocok diperankan oleh Meriam Bellina. Selain itu sikap sinis, terlalu berlebihan, dan realistis menjadi cirinya untuk menghina Gading, yang disangka meminta upah ketika menolong Aida. Tokoh Ibu Farida ini memiliki usaha tenun dirumahnya, pekerja keras, dan bijak ketika memberikan nasihat pada Aida (anaknya). Salah satu sikapnya yang terlalu berlebihan adalah ketika meminta Arman untuk menolongnya mencari Aida di Pelabuhan.

$$
\text { Pamone (Deden Bagaskara) }
$$

merupakan seorang tokoh nelayan dan Bapak dari Ondeng. Sikapnya yang baik hati, sayang pada Ondeng, bijaksana, 
FON ; Jurnal Pendidikan Bahasa dan Sastra Indonesia

Volume 13 Nomor 2 Tahun 2018

membuat Ondeng tidak ingin jauh Kabupaten Muna Provinsi Sulawesi darinya. Selain itu sikap Pamone yang Tenggara. Di sana, dikisahkan terdapat rendah hati membuat Gading ingin jembatan yang begitu rapuh. Latar tempat menganggap sebagai bapaknya. Pada jembatan yang rapuh ini adalah latar pertengahan film Pamone ini meninggal tempat yang sering dilewati oleh Inal, Nia, dunia ketika sedang berlayar di tengah Yanti dan Aska ketika akan menyebrang malam. Ombak dan angin besar yang untuk pergi ke SD Towea.

membuat perahu Pamone terbalik dan terbawa ombak.

Tokoh Attar (Vickram Priyono) adalah tokoh yang murid yang paling nakal. Ia suka mengejek, jahil, dan usil. Tokoh Attar ini merupakan tokoh antagonis dan sombong. Selain itu, tokoh Attar ini merupakan adik kandung dari Arman. Sikapnya yang jahil terlihat ketika ia suka mengejek Ondeng dikelas. Arman (Agung Saga) merupakan kakak dari Attar, memiliki karakteristik suka menolong, baik hati, jujur, suka pada Aida, tampan, hobi berkuda, anak dari pemilik peternakan sapi, dan bertanggung jawab.

Berdasarkan analisis tokoh, diperoleh representasi bahwa setiap tokoh dihadirkan untuk mewakili gagasan tertentu. Gagasan tersebut berkaitan erat dengan pendukung dan penentang terhadap pendidikan. Pendidikan sangat dipengaruhi oleh latar yang terdapat dalam cerita. Latar utama film Jembatan Pensil ini adalah Pantai Meleura SD Towea ini merupakan latar tempat saat siswa sedang belajar. SD Towea inipun merupakan sekolah yang didirikan oleh Pak Guru, dengan dana dan tenaganya sendiri. Selain itu, latar tempat SD Towea ini yang sering muncul pada film. Dalam film terdapat latar tempat berupa masjid. Latar tempat Masjid ini dimunculkan ketika adanya pengajian di Kampung tersebut saat adegan Pak Ustadz yang sedang memberikan ceramahnya pada warga sekitar dan untuk menunjukkan bahwa masyarakat adalah warga yang religius.

Selain latar tersebut, terdapat pula latar Toko Roti, halaman rumah Inal dan Nia, dan rumah Ondeng yang digunakan untuk merepresentasikan jalinan persahabatan antara Ondeng dengan teman-temannya. Latar tempat rumah Ondeng digunakan pula untuk menunjukkan posisi Ondeng di masyarakat. Ondeng yang notabene memiliki keterbelakangan mental tetapi memiliki banyak teman dan orang begitu 
FON ; Jurnal Pendidikan Bahasa dan Sastra Indonesia

Volume 13 Nomor 2 Tahun 2018

peduli padanya menunjukkan bahwa

Dalam gua itu Aida mengajarkan tulisanOndeng adalah pribadi yang baik.

Pada film ini terlapat latar pasar ikan, peternakan sapi, dan perahu. Latar ini digunakan untuk menunjukkan identitas para tokoh yang berada di kelas menengah ke bawah. Deskripsi ini menegaskan bahwa pendidikan relatif lebih sulit diakses oleh masyarakat menengah ke bawah.

Bukit Pulau Muna menjadi salah satu latar tempat dalam film Jembata Pensil. Adegan yang ada di latar tempat ini adalah ketika Aida mengajak semua muridnya pergi ke alam untuk belajar. Bukit ini juga menjadi tempat Gading yang selalu mengajarkan Ondeng banyak hal, salah satunya adalah memberikan amanat "seorang nelayan itu hidup dan matinya adalah dilaut” itu adalah salah satu ujaran Gading pada Ondeng.

Meskipun pendidikan dalam film ini dikisahkan sebagai sesuatu yang sulit diraih, dalam film ini pun dikisahkan betapa pendidikan tidak tersekat oleh tembok dan bangunan. Pendidikan dapat dipelajari di mana saja dan kapan saja, tidak terbatas pada pendidikan formal. Hal itulah yang diajarkan oleh Bu Guru Aida. Dalam gua Liang Kabori, Aida mengajak muridnya untuk belajar pada alam. Salah satunya adalah mengunjungi Gua tersebut.

\section{SIMPULAN}

Berdasarkan paparan di atas, dapat disimpulkan bahwa film ini merepresentasikan sulitnya meraih pendidikan. Meninggalnya tokoh Ondeng yang dikisahkan memiliki kesadaran terhadap pendidikan dan kepedulian terhadap lingkungan sekitarnya, digunakan untuk menggugah penonton untuk lebih peduli terhadap pendidikan. Selain itu, film ini juga dapat dinilai sebagai sarana persuasi terhadap 
FON ; Jurnal Pendidikan Bahasa dan Sastra Indonesia

Volume 13 Nomor 2 Tahun 2018

penonton untuk melakukan kerjasama dalam membangunkan bangsa: bahwa memajukan bangsa terutama dalam bidang pendidikan bukanlah tugas satu orang melainkan tugas bersama.

\section{DAFTARPUSTAKA}

Dewantara, K.H. (2004). Karya Ki Hadjar Dewantara (Cetakan Ketiga). Yogyakarta: Majelis Luhur Persatuan Taman Siswa.

Harini, Y. N. A. (2012). “Transformasi Folklore Lisan Nini Anteh ke Novel Dongeng Nini AntehKarya A.S Kesuma.” Jurnal Pendidikan Bahasa dan Sastra. [Daring] Tersedia di: ejournal.upi.edu/index.php/BS_JPB SP/article/view/3706
Jabrohim. (1996). Pasar dalam Perspektif Greimas. Yogyakarta: Pustaka Pelajar.

Lamb, B. (2013). “Media Representation”. Media in Minutes Episode 7. [Daring] https://www.youtube.com/watch?v= fOecpti7Qf8 (Diakses pada 25

Oktober 2017)

Wanda, A., (2017). Jembatan Pensil. Diperoleh 20 September 2018 dari https://www.skenariofilm.com/2017 /08/Jembatan-Pensil-2017.html Wiyatmi. (2013). Hakikat Sosiologi Sastra. Yogyakarta: Kanwa Publisher. 